\title{
THE THEORIES OF CORPORATE GOVERNANCE AND SUGGESTED SOLUTIONS TO ITS LEGISLATION COMPLETION IN VIETNAM
}

\author{
HO NGOC HIEN \\ Graduate Academy of Social Sciences, Vietnam \\ PHAN DANG HAI \\ Banking Academy, Vietnam
}

\begin{abstract}
Currently, there are three popular theories of corporate governance widely applied in the field of jurisprudence worldwide. They are Agency Theory, Stewardship Theory, and Stakeholder Theory. Based on these theories, the article focuses on clarifying legal issues about corporate governance, thereby suggesting solutions to the improvement of corporate governance legislation in Vietnam at present time.
\end{abstract}

Key words: Corporate governance, corporate governance legislation, Vietnam.

Cite this Article: Ho Ngoc Hien and Phan Dang Hai, The Theories of Corporate Governance and Suggested Solutions to its Legislation Completion in Vietnam, International Journal of Management, 11(12), 2020, pp 12-19.

http://iaeme.com/Home/issue/IJM?Volume $=11 \&$ Issue $=12$

\section{INTRODUCTION}

Generally, corporate governance (CG) can be understood as a set of relationships between shareholders, the Board of Directors (BOD), managers, and other related parties. CG also establishes a mechanism to build corporate goals, identify the means to achieve those, and monitor goal performances (OECD, 2015, p.6). The major challenges to all CG issue have remained unchanged throughout history: It is impossible to expect the BOD of a company, who manage the money of other people, to be just as cautious as when they do of their own (Smith, 1776). The operation of a company needs a "collective effort" by owners of the resources it needs (Alchian \& Demsetz, 1972). Therefore, the distribution of the company's burdens and rewards should be fair. Moreover, while the model of most modern companies is joint-stock companies, including listed companies, the gap between shareholders - the owners, and the BOD members is also greater, BOD members have more power, and some of them abuse it (Berle \& Means, 1932). 
Since the 1990s, the development of CG theories has attracted researchers' interest in CG. Those theories are Human resource dependency theory, Managerial and Class Hegemony; Social Contract theory, Legitimacy theory, Agency theory, Stewardship theory and Stakeholder theory... mong which, the three last theories are widely used in jurisprudence researches.

In legal science research, research theories play an extremely important foundation. With regard to CG, the three theories Agency Theory, Stewardship Theory and Stakeholder Theory can be identified as "guidelines", "keys" for lawmakers to issue legal regulations on CG in which each theory gives its own perspective based on different research approaches. Hence, in doing research on CG legislation, it should be viewed from different angles of theories so as to ensure generalization and comprehensiveness.

\section{FINDINGS AND DISCUSSION}

\subsection{Three theories of corporate governance and the fundamental problems}

\subsubsection{Agency theory}

Agency theory is derived from an economic theory developed by Alchian and Demsetz in 1972, then further developed by Jensen and Meckling in 1976. Jensen and Meckling (1976) explained as follows: Agency Theory refers to a contract under which one or several principals (shareholders) hire other agents (company executives) to perform certain services on their behalf, including the decision-making authority. In some cases, if both parties want to maximize the benefits, there is reason to believe that the agents will not act in the priorities of the owners.

From the Agency theory point of view, the agents generally have more priorities. They do not always maximize the company profits; they have privileges to possess company resources. There are countless instances in which the managers consider the company as their property, taking advantage of their position in the company, enjoying the benefits not belong to them, and receiving bonuses unrelated to business running, which results in shareholders' loss.

Agency theory focuses on the following issues: i) How to build an incentive and followup system to prevent the agents from risking the principals' assets, or to be more precise, a system that makes the agents behave as if they are trying to maximize the proxy's benefits? ii) How a representative system reaches the most efficiency under imperfect circumstances? (Coriat \& Weinstein, 1995, p.139).

To solve these above problems, there are two mechanisms proposed by Agency theory that the laws, as well as the company, can apply: i) Independent board members, and ii) Remuneration and rewarding benefits for managers. By awarding managers the shares of the company and the company's business results, the agent interests will increase and be aligned with that of the owners (Baker \& Anderson, 2012). Therefore, in order to protect their interests, the owners should sign a contract that describes exactly what the executives must do and how profits are distributed, however, this is not possible in reality because of unexpected events that could happen afterward. Shareholders, in this case, are bound to trust members of the BOD. The trust results in an agreement in which parties have the disproportionate right in accessing information: BOD members know more about the company than shareholders do. While board members may risk company funds in more risky projects than shareholders expect, shareholders and potential investors can only assess the ability of Board-level decision-makers and their risk profiles from prospectus, reports and past performance of the company, the minimum information required by the company and the law. 


\subsubsection{Stewardship Theory}

The Stewardship theory considers CG from a different point of view from the Agency theory, reflecting the initial legal view on the company. Davis and Donaldson (1991, p.21) argued that so-called good managers would work for the best interests of shareholders.

Basically, each company is established as a separate legal entity. Shareholders holding shares of the company nominate and appoint members of BOD. These will then be managers, or stewards, for their interests. Members of the Board of Directors have the responsibility to report to shareholders the results of such management in the role of the shareholder interest managers. The managers act towards organizational and collective orientation, not always in the way of maximizing their interests. They should perform their responsibility with independence and integrity, basing on the interests of the company, because the managers seek to achieve the company's goals (Davis, Schoorman \& Donaldson, 1997, p.24). According to Smallman (2004), where the interests of shareholders are maximized, the interests of managers are maximized, too because the success of the organization will satisfy most of the requirements and managers will have an obvious mission.

Davis, Schoorman, and Donaldson (1997) argue that both Agency theory and Stakeholder theory represents the so-called prisoner's dilemma, a problem often considered central to game theory. If the managers act as agents and shareholders expect them to do so, then a high degree of control through a strong, independent board will minimize the risk. If managers act like stewards and shareholders expect them so, then the next belief will be in the right place. The dilemma will intensify when shareholders and managers disagree over their views on their role. If shareholders expect stewardship but the managers act as agents, the executives will be likely to make use of the value of the company for their purposes. If they are oriented for stewardship and shareholders react as consistent, tight controllers, the managers will become frustrated, quit, or underperformed (Baker \& Anderson, 2012, p.247).

The Stewardship theory, up to now, has also received quite a lot of criticism. In listed companies, for example, shareholders are further and further away from the company and not nominating members of the board. They argue that financial reports are easily understood for experts only. The company lacks transparency in complicated issues and Board members are not truly accountable to shareholders. Others argue that the Stewardship theory is rooted in law so it is nominal, it emphasizes what to do or even promotes it. Since the collapse of companies in the late 20th and early 21st century, Tricker (2012) argued that the trust members of the BOD have under the stewardship model has been eroded, this causes adverse effects on investors, shareholders, and the community.

\subsubsection{Stakeholder Theory}

The previous CG theories significantly contrast with the two roles of the BOD - control and value creation - but now include one more, stakeholders' interest concerns. Stakeholder theory has been introduced to the management since 1970 and has gradually been developed by Freeman (1984) combining corporate responsibility with related parties, including individuals, organizations that have a certain concern or interests in the company: owners, employees, trade unions, and outside parties such as lenders, suppliers, customers, communities and society.

According to the Stakeholder theory, a company is a system of parties operating in a large social network. The society provides the legal and market framework for the company's operation. The purpose of a company is to create value and prosperity for stakeholders by converting their interests into products and services and to increase their wealth (Clarkson, 1995). Stakeholder theory proposes strengthening voices and providing incentives for stakeholders such as their ownership of the company (Muth \& Donaldson, 1998). These 
measures include allowing employees to hold shares and appointing related parties such as customers, suppliers, financial advisors, employees, and community representatives as board members.

It can be seen that the Stakeholder theory is broader than the Agency theory, where the responsibility of the Board is not only limited to the interests of each shareholder but towards the interests of many other related parties. Concerns towards related parties used to be overshadowed in the free market with the 1980s 'growth and ambition' stance, but now the matter reappears. The narrow focus on shareholders has extended to a larger group of related parties, according to Freeman (1984), Donaldson \& Preston (1995), Freeman, Wicks \& Parmar (2004), those are interest groups related to social, environmental and ethical issues. And also for that reason, concepts such as corporate social responsibility, business ethics, or corporate sustainability reporting, respectively emerge, occupying an important position in current legal concerns as well as in the activities of any company.

\subsection{Some suggested solutions to the improvement of corporate governance legislation in Vietnam at present}

In Vietnam today, the CG legal framework has been formed with many relatively progressive contents. From the amended legal documents on CG in general such as Enterprise Law, or in specialized fields such as Law on Securities, Law on Credit institutions, sub-law documents ... have been continuously amended and supplemented by competent agencies to meet the requirement of legal completion[1]. It is also worth noting that, in recent years, the State Securities Commission of Vietnam has cooperated with IFC to develop the CG Code of Conduct in accordance with best practices. The main purpose of this document is to provide guidelines and recommendations on CG best practices for public companies. Like many countries throughout the world, the building of the CG Code of Conduct is an urgent requirement in the globalization process. This is considered to be the last missing piece to complete the overall picture of the unfinished CG legal framework in Vietnam during the past years.

An easy-to-see issue is that corporate laws in general and CG laws in particular in Vietnam are increasingly influenced by UK-US laws (Ngo Huy Cuong, 2016). With the growth of the economy of countries in the traditional UK - US laws, developing countries including Vietnam are actively importing the UK - US corporate law provisions to create intimacy, which enables companies to easily establish economic ties despite having different nationalities. From the regulations on the CG model, conditions, and requirements for managers and executives; the problem of preventing conflicts of interest ..., it is not difficult to recognize how the provisions of the Vietnamese Enterprise Laws have changed to be in accordance with reality over different periods of time. From a positive view, CG standards in Vietnam have been completed relatively synchronously with the legal provisions throughout the world, creating conditions for improving the effectiveness of CG in practice. However, the process of implementing legal regulations on CG - sometimes is judged to be out of bounds in socio-economic conditions in Vietnam - that poses another challenge to related subjects. Although companies have already been aware of the importance of CG as well as improved CG operations towards more openness and transparency, mistakes become more and more popular, mostly focusing on very basic issues such as: i) Shareholder rights protection; ii) Organization and operation of the BOD; iii) The independence of the Supervisory Board; and iv) Information disclosure regime[2]. These shortcomings not only originate from existing socio-economic foundations and awareness of companies, but also from shortcomings of current legal regulations. 
In general, because the development and completion of legal regulations on CG in Vietnam are mainly learning from other countries', in response to the integration trend, it means a lack of general studies, especially very few based on $\mathrm{CG}$ theoretical foundation, so that legal provisions on CG in Vietnam are inconsistent and encounter many shortcomings. This is reflected in the fact that in the process of promulgating the Enterprise Law in Vietnam, in just 15 years, from 2005 to 2020, there have been 3 documents of the Enterprise Law issued $(2005,2014,2020)$ with many changes related to CG. At present time, although CG legal regulations in Vietnam have solved the fundamental problem of CG - the relationship between shareholders and managers, executives, however, for other issues, especially the relationship with related parties, there have not been many specific regulations yet. The regulations on the protection of shareholder rights, ensuring the operation of the Board of Directors as well as the independence of control institutions still show weakness in the enforcement ability in practice.

In the coming time, the improvement of legal regulations on CG in Vietnam must still be on top priority. Based on the analysis on the theoretical basis of CG as well as assessing the current situation of CG legislation in Vietnam, the authors would like to give some suggestions in completing the CG legislation in Vietnam as follows:

\subsection{Firstly, CG legislation should increase the value and protect the interests of shareholders as well as ensure fair and harmonious interests of all related parties}

Stemming from the Agency theory, CG activities should firstly create long-term economic profits to increase the value of shareholders (investors) to attract capital in the context of global competition for capital. The CG regulations need to recognize, protect, and facilitate the exercise of the fundamental rights of shareholders. The CG legislation also needs to emphasize fairness among investors, especially between minority shareholders and the ones holding control of the company. Besides, the legal provisions should aim to control arbitrary management over the use of capital without making profits, as well as set strict requirements for the transfer of assets from minority shareholders to those with control of the company, or for transactions likely to carry an element of false interest and other insider misleading at the critical level of management. This requires the law to clearly define the rights, duties and responsibilities of the managerial entities in the CG structure, in which special attention is paid to the supervisory role of shareholders and other entities who implement other independent monitoring capabilities.

Also, in the CG system, the related parties always have conflicts of interest, of course, those are legitimate interests. In resolving a conflict of interest in the process of building a legal rule, lawmakers should choose either of the two options: totally sacrifice one benefit (of course with satisfactory compensation) to preserve the other interest; or reconcile each benefit slightly, so that both can continue to exist peacefully in the same home. Whichever way is chosen, the building of laws to resolve conflicts of interest should be placed in a strict mechanism, aiming to produce rules that satisfy the criteria of fairness.

The company's success is associated with the ability to reconcile interests between BOD members, directors, and other managerial positions with the interests of shareholders. Performance-based remuneration is seen as an effective tool to achieve this goal. In this respect, CG legislation should create a contractual framework to encourage the efforts of the key personnel in the company. These regulations should therefore not limit the flexibility in regulating interests between shareholders and senior managers and other beneficiaries. Excessive restrictions may erode entrepreneurship and adversely affect the company's performance. 
In addition, it should be noted that the company's competitiveness, status, and success are the results of collective efforts including contributions from various resources such as shareholders, potential investors, banks, employees, creditors, customers, suppliers, the government.... Each party contributes to a different aspect; Shareholders, investors, banks provide capital for the company operation, the employees provide human resources, the government provides policies, customers bring in revenue, etc. Stakeholder contributions are a valuable resource to build competitiveness and increase profits for the company. The interests of any affected subjects will also affect the company's business results. Therefore, CG legislation should reflect the principle: A company can only achieve optimal benefits when respecting the interests of all related parties and their contribution to the long-term success of the company. (OECD, 2015, p.34).

Admittedly, this is a difficult and complicated task while the "written" law mainly governs corporate relationships, the relationship between the involved parties is based on the "unwritten" factor of business culture (Le Minh Toan, 2010). Therefore, in this company's network of interests, regulations should also clearly define what regulatory relationships are in order to have a specific direction of impact, for example, the direction of adjustment will be different from the relationship between shareholders and managers and the relationship between the company and the creditors, based on that to build regulations on the responsibilities, obligations of the managers as well as regulations on preventing interest conflicts under predetermined goals.

\subsection{Secondly, CG legislation should recognize and ensure the independence of the BOD and control institutions in the company}

From the point of view of the Stewardship theory, the BOD and control institutions are the bodies elected by shareholders to monitor and manage the company. To some extent of their authority, they are responsible for protecting and combating the fraud, waste of property, or ineffective performance of the Directors or the managers. Maintaining active and independent members will create professionalism with truly dedicated, knowledgeable, and dynamic individuals regardless of the CG models varies from country to country (single-level boards or supervisory boards - two levels). Good CG practices have affirmed the role of independent board members and control institutions, which is very important to the quality and effectiveness of $\mathrm{CG}$ operations as these members can bring value to the company by providing independent and objective assessments as well as providing ideas to help create new business opportunities. They may also provide constructive rebuttals that are rarely found within the company (IFC, 2010). Therefore, the CG legislation should specify the followings:

i) Clearly define the authority of independent board members and that of other control institutions in the CG model. This assignment is based on compliance with the principles and position of that agency in the company, ensuring that there is no overlap or conflict in terms of authority.

ii) Increase the number and quality of corporate supervisors through regulations on the structure of the board, conditions, and standards for these subjects, for example ensuring an appearance of non-executive members of the Board and independent board members with certain percentages as well as prohibitions on holding multiple positions inside or outside the company, especially in public companies or listed ones.

iii) Facilitating the supervising entities to properly perform their assigned responsibilities through the provision of supervisory power of independent board members, the Internal Audit Committee[3], the Supervisory Board, or other institutions for the management and administration activities of the BOD and the Directors. At the same time, it is also necessary to specify more details about the responsibilities and obligations for these people, this is one 
of the bases to investigate their legal liability when they perform improperly their duties, affecting the rights and interests of shareholders and related parties, avoiding the fact that these entities operate formally and ineffectively in the companies (Phan Dang Hai, 2018).

\section{CONCLUSION}

The three main theories about CG above show many approaches in building CG law: i) With the Agency theory, the law should focus on supervising the managers and executives to ensure that they run the company for the company's benefit; ii) The Stewardship theory focuses on helping and empowering the managers and executives, thereby creating the most effective CG motivation, and at the same time, emphasizing their responsibility of "prudence, loyalty, honesty"; iii) With the theory of stakeholders, the law should set out requirements that all stakeholders of the company should be included in the governance structure to ensure that the company operates for their benefits ... From these approaches, countries, especially developing ones like Vietnam need to pay special attention to the effectiveness of the construction and completion of the corporate governance legislation in the future.

\section{REFERENCES}

[1] A. Alchian \& H. Demsetz (1972), Production, Information, Costs and Economic Organization, American Economic Review, Vol.62, No.777-795.

[2] ACMF (2012, 2014, 2016), ASEAN Corporate Governance Scorecard.

[3] Benjamin Coriat \& Oliver Weinstein (1995), New Theories of Enterprise (translated from the original: Les Nouvelles Théories De L'entreprise), The Knowledge Publishing House.

[4] Berle, A. and Means, G. (1932) The Modern Corporation and Private Property, Commerce Clearing House, New York.

[5] Bob Tricker (2012), Corporate Governance: Principles, policies and practices, first edition, DT Books.

[6] C. Smallman (2004), Exploring Theoretical Paradigm in Corporate Governance, International Journal of Business Governance and Ethics, Vol.1, No.1, pp.78-94.

[7] Voting for Listed Companies in 2018 (2019), Report on CG assessment of listed companies in Vietnam.

[8] G20 / OECD (2015), Principles on Corporate Governance.

[9] H. Kent Baker \& Ronald Anderson (2012), Corporate Governance - A synthesis of theory, research, and practice, Ho Chi Minh City Economic Publishing House.

[10] IFC (2010), Frequently Asked Questions about CG, page 7.

[11] James H. Davis, F. David Schoorman \& Lex Donaldson (1997), Toward a Stewardship Theory of Management, The Academy of Management Review, Vol.22, pp.20-47.

[12] Le Minh Toan (2010), Management of public companies, listed for businesses and investors, National Political Publishing House.

[13] Lex Donaldson \& James H. Davis. (1991), Stewardship Theory or Agency Theory: CEO Governance and Shareholder Returns, Australian Journal of Management, Vol 16, pp.49-64.

[14] Max BE. Clarkson (1995), A Stakeholder Framework for Analysing and Evaluating Corporate Social Performance, Academy of Management Review, Vol.20, No.1, pp.92-117.

[15] Melinda Muth and Lex Donaldson (1998), Stewardship Theory and Board Structure: A contingency Approach, Corporate Governance - An International Review, January, Vol 6, pp.2-28. 
The Theories of Corporate Governance and Suggested Solutions to its Legislation Completion in Vietnam

[16] Ngo Huy Cuong (2016), The impact of law on Vietnam's private law, updated 11/02/2020. $<$ https://thongtinphapluatdansu.edu.vn/2016/11/22/01-6/>

[17] Phan Dang Hai (2018), Development trend of law on corporate governance in the world and issues posed with Vietnam, Journal of Lawyers, No. 4/2018, p.85-90.

[18] R. Edward Freeman (1984), Strategic Management: A Stakeholder Approach, Pitman Publishing, Boston, MA.

[19] Thomas Donaldson and Lee E. Preston (1995), The Stakeholder Theory of the Corporation: Concepts, Evidence, and Implications, The Academy of Management Review, Vol. 20, No. 1, pp.65-91.

[20] Vietstock \& FiLi (2017), Report on survey and disclosure of information on Vietnam stock market 2017.

[21] The Law on Enterprises 2014, the Law on Securities 2006 (amended and supplemented 2010), the Law on Credit Institutions 2010 (amended in 2017) are the current documents being applied in Vietnam. As of January 1, 2021, the Enterprise Law 2020 and the Securities Law 2019 are new documents that will officially take effect.

[22] Documents under the Law on CG for public companies include Decree 71/2017/ND-CP and Circular 95/2017/TT-BTC on CG of public companies.

[23] Refer to the evaluation to see the CG situation in Vietnam is still limited in many contents:

[24] ACMF - ASEAN Regional Capital Market Forum (2012, 2014, 2016), Report on ASEAN Regional CG Scorecard.

[25] Vietstock \& FiLi (2017), Report on survey and disclosure of information on Vietnam stock market 2017

[26] Voting for Listed Companies in 2018 (2019), Report on CG assessment of listed companies in Vietnam.

[27] This agency is renamed under the Enterprise Law 2020 (effective 01/01/2021) as the Audit Committee. 